\title{
THE CRACK USER AND THE CARE NETWORK: INTERVENTIONS AT THE UNIFIED HEALTH SYSTEM IN SOUTHERN BRAZIL
}

\author{
Sílvia Schein, Laíssa Eschiletti Prati \\ Faculdades Integradas de Taquara, Brazil \\ E-mail: silviaschein@yahoo.com.br, laissa.prati@gmail.com
}

\begin{abstract}
Crack consumption is being a problem that challenges health systems all over the world. In Brazil, changes in public policies were trying to organize the net of services that deal with this public. This paper presents how the public health system is organized and what are the interventions adopted in the different services that attend crack users. Using Ecological Insertion, researchers followed the everyday interventions at different services during three months (in each place). All the observations were registered in field diaries that were qualitatively analyzed. The data collection happened in three hospitals, six psychosocial attention centers, and five basic health unities in Paranhana Valley, southern Brazil. These services are distributed in different levels of attention in the health system. Results show that treating crack users still is a challenge for the system. The services must work integrated and adequate to the user demands. The multidisciplinary work is fundamental (involving psychiatry, psychology, social work and physical education). Different treatment approaches are needed, keeping the crack dependents and their family attended. The general hospital is the preferential therapeutic strategy. The basic health unities do not recognize their responsibility with this public and the psychosocial centers has the feeling that what are offered doesn't attend the dependent demand. Despite the efforts to provide quality service, professional specialization and commitment with the patients are aspects that must be improved.
\end{abstract}

Key words: crack cocaine, health care (Public Health), psychology, social, public policy.

\section{Introduction}

Psychoactive drugs have been a part of society since ancient times in many cultures and religions. Their use has had many purposes, but these always involve the alteration of consciousness. Consumption and dependence, however, have increased significantly from the mid-twentieth century and have reached colossal proportions, becoming a worldwide public health problem (Pratta \& Santos, 2009).

The increase in drug use and addiction has been corroborated by several longitudinal studies in Brazil. They began in the late 80s and have been held at different time intervals, providing information on the changes in consumption patterns in Brazilian society. Among these studies, the National Survey on Drug Use among Students of Elementary and Secondary Education of the Public Education System (1987, 1989, 1993, 1997 and 2004), the Survey on Drug Use among Children and Adolescents Living on the Streets (1987, 1989, 1993, 1997 and 2003), the House- 
ISSN 2029-8587

PROBLEMS

OF PSYCHOLOGY

IN THE $21^{\text {st }}$ CENTURY Volume 6, 2013

56

hold Survey on the Use of Psychotropic Drugs $(1999,2001,2005)$ (Galduróz, Sanchez \& Noto, 2011), and, more recently, the National Survey of Alcohol and Drugs (Laranjeira, Pinsky, Zaleski \& Caetano, 2007; Laranjeira, Madruga, Ribeiro, Pinsky, Caetano \& Mitsuhiro, 2012) can be mentioned. The Ministry of Health (Brasil, 2004a) has acknowledged drug use as a public health problem. As such, it has taken on the challenge of preventing, treating and fully rehabilitating users of alcohol and other drugs.

The gradual increase in the consumption of crack, in particular, has caused alarm among health professionals and in society. A United Nations report (UN, 2012) has signaled an increase in cocaine use in Brazil, especially since 2010, with the number of seizures increasing significantly. Currently, Brazil is considered to be the largest crack market in the world (Laranjeira \& cols., 2012). Crack is obtained by heating the cocaine base paste with substances such as sodium bicarbonate and adulterants, creating crystals that are smoked in pipes or other improvised objects (cans). It is a stimulant of the central nervous system. Its effects are quick, brief and intense. The euphoria occurs 10 seconds after inhalation, peaking between 5 and 10 minutes. The speed, in which the effects are achieved, is one of the factors contributing to the high addictive power of crack (Kessler \& Pechansky, 2008; Ferri, Laranjeira, Silveira, Dunn \& Formigoni, 1997).

Crack use causes neurological, biological, psychological and social damage to the addict and the speed with which this occurs, causes concern in health professionals and overwhelms the healthcare system. There is more demand for treatment of crack addicts than of cocaine users (Duailibi, Ribeiro \& Laranjeira, 2008; Laranjeira \& cols., 1997). Crack users, however, have the lowest adherence to treatment among all other drug users (Ferri \& cols., 1997; Pulcherio, Stolf, Perrenon, Fensterseifer \& Kessler, 2010). Kessler and Pechansky (2008) highlight the fact that crack is a drug habit that is difficult to treat, especially in the context of the Brazilian model of care to the drug user.

The treatment of crack users, therefore, has proven to be a challenge for both the care network and for public policies (Ribeiro \& Laranjeira, 2012). It requires coordinated intervention and action of different spheres of government and of the care network itself. As a consequence, several changes have occurred in recent years concerning the public health policies that are aimed at dealing with this challenge. In addition, there have been financial incentives to increase the number of beds in general hospitals (Brasil, 2012b), to improve health services, such as the Psychosocial Attention Center (PSAC, Brasil, 2013) and the Family Health Support Centers (FHSC, Brasil, 2012c), and to hire beds in Therapeutic Communities (nonprofits) for the care of drug users (Brasil, 2012a).

The survey "Characterization of the Care Network of Crack users in the Paranhana Valley - Rio Grande do Sul - Brazil" has mapped the care services, the local proposals for therapeutic action, the access barriers and difficulties encountered by users in the search for treatment and/or in the treatment itself. From this vantage point, the present study aims to present the results for the Care Network of the Unified Health System (UHS) of the Paranhana Valley/Rio Grande do Sul/Brazil regarding its organization and proposed care services for the crack dependent.

\section{Theoretical Review}

The right to free health care, defined as a duty of the State, was consolidated in the Constitution of 1988. It presumes the implementation of policies that promote the improvement of health care for the population as a whole, ensuring universal access to the actions and services that aim to promote, protect and recover health (Brasil, 1988). The Brazilian UHS was created in 1988 and comprises the public health services and actions that form a regionalized and hierarchical network. Its guiding principles are universality, equity, and a comprehensive approach to care and community participation (Brasil, 1990a). The services are regulated by Law 8,080 (Brasil, 1990a), which provides for the conditions for the promotion, protection and recovery of health, the organization and functioning of the services; and by Law 8,142 (Brasil, 1990b), which ensures community participation in this system.

For years the care of drug users in Brazil was neglected, leaving the responsibility to justice, public safety, and education institutions and to charitable or religious associations (Brasil, 2005a). Until the mid-twentieth century, psychiatric care for drug users was based on a hospital 
centered model, where dependents were sent to psychiatric institutions as a way to remove them from society and preserve the morals of society (Pratta \& Santos, 2009.) The adopted practices were psychiatric or religious in nature and were aimed at total abstinence. Furthermore, the use of drugs was associated with criminality and antisocial behavior (Brasil, 2005a).

The approval of the Psychiatric Reform Law No. 10,216 in 2001 has led to the gradual replacement of psychiatric beds by a Network of Integrated Mental Health care, ensuring the protection of the rights of individuals with mental disorders. This law covers individuals with mental disorders and those arising from the consumption of alcohol and other drugs (Brasil, 2001).

In 2002, as the necessity arose to define specific strategies for drug user care, the Ministry of Health implemented the National Program for Integrated Community Care of Alcohol and other Drug Users (Brasil, 2005a). In 2004, it instituted the Policy for Integrated Care of Alcohol and Other Drug Users. This policy is based on the principle of organizing the actions related to the promotion, prevention, protection and education of people who use drugs, and has an approach that uses harm reduction as a guideline (Brasil, 2004a). The National Policy on Drugs (Brasil, $2005 \mathrm{~b}$ ) contains guidelines on the care for drug users, such as their treatment, rehabilitation, social reintegration and the reduction of social and health injuries. In addition, it provides guidance on the prevention, reduction of the supply, studies, research and evaluations about drugs in Brazil.

The Health Care Network is the set of health services and actions that are coordinated at increasing levels of complexity. It aims to ensure the comprehensiveness of the health care system in a given territory, taking into account its economic, social and cultural characteristics (Brasil, 2005a). The Psychosocial Care Network is part of the Health Network, and it assumes that the mental health services and actions are a reference and are arranged in such a way as to care in a coordinated and integrated way for individuals with mental disorders, including those with demands arising from the use of drugs (Brasil, 2011).

In 2011, the Ministry of Health established the "Network for Psychosocial Care of People with Mental distress or disorder and Needs Arising from the Use of Drugs" (Brasil, 2011), expanding the focus of care of "the Integrated Mental Health Network" that was in place since 1992 (Vasconcelos, 2008). This policy aims to integrate the care network for drug users in a coordinated and effective way, expanding and diversifying the actions taken by the services (Brasil, 2011). This model is centered on a community and territorial network, which aims to establish partnerships that can enable health treatment, prevention and promotion activities to occur continuously (Brasil, 2005a; Delgado \& Cordeiro, 2008). Its premises are the regionalization, decentralization and comprehensiveness of the care for the population's mental health (Brasil, 2005a). It established a set of references for users, focusing on rehabilitation and social reintegration. It is composed of Primary Care, Specialized Care, Urgent and Emergency Care, Temporary Residential Care, Hospital Care, Deinstitutionalization Strategies and Psychosocial Rehabilitation (Brasil, 2011).

Primary Care covers the Basic Health Units (BHU), the Primary Care Teams for specific populations, such as the teams for ambulatory consulting and support services for Residential Care, and the Social Living Centers (Brasil, 2011). These programs are characterized by direct access to the population, encouraging the establishment of bonds and trust. The BHU are the gateway to the health system. It's up to them to organize and optimize the operation of the network. The development of interventions involving users, families and communities is of vital importance, not only to prevent health problems and promote health care, but also to reduce harm (Delgado \& Cordeiro, 2008).

Specialized Psychosocial Care in its different forms is conducted by the Center for Psychosocial Care (PSAC). It is an open, community health service, which is considered the place of reference and treatment for people with severe and persistent mental disorders, and also for alcohol and other drug users when there is no Psychosocial Attention Center for Alcohol and Drugs (PSAC $\mathrm{AD})$ in the Town. It aims to encourage and facilitate the social rehabilitation of the individual, to recover and strengthen the ties with his family and the community to which he belongs. The PSAC AD cares exclusively for people with disorders related to drug use and addiction (Brasil, 2004a, 2011). It works in a coordinated way with the entire Mental Health Care Network and takes care of the most serious cases (Brasil, 2004b).

Urgent and Emergency Care services are meant to handle and care for people in emergency 
ISSN 2029-8587

PROBLEMS

OF PSYCHOLOGY

IN THE $21^{\text {st }}$ CENTURY Volume 6, 2013

58

situations. Hospital Care comprises both the Specialized Ward in a General Hospital, which cares for users experiencing severe intoxication or withdrawal, and the Referral Hospital, which will provide support through short hospitalizations (Brasil, 2011). This resource is highly complex, and should only be accessed when all other resources have been exhausted (Brasil, 2004a).

Despite the change in the way that the drugs problem is handled, the increase in drug use has not reduced as expected over the years. The jump in the consumption of crack and its accompanying damages to the user, the health system and society in recent years, has prompted the Federal Government to establish the Integrated Plan to Combat Crack and Other Drugs in 2010 (Brasil, 2010a). This plan provides for an increase of beds in General Hospitals and Therapeutic Communities, the expansion of the care network for crack and other drug users (regional 24h PSAC $\mathrm{AD}$, transitional shelters and family health support centers) and the training of the professionals of the health network (OBID, 2010).

The reform of the psychiatric system and the creation of substitute mental health services configured a new field of activity for Psychologists, who previously were restricted to Psychiatric Hospitals and private clinics. Their incorporation into health care teams has provoked resistance from some professionals who didn't understand the role of psychologists, who for their turn lacked the theoretical and practical foundation to be part of such teams. Psychologists didn't know where or with whom to intervene, or even how to act, and so they reproduced the traditional model of clinical psychology (Spink, 2003). Their contact with the public health system required them to rethink the way they worked and cared in the face of a new social reality, a poor patient base with demands that were related to their economic and social conditions (Gama \& Koda, 2008).

The health system is strongly influenced by the biomedical model, focusing on the disease rather than on the person and integration. This approach excludes the subjective experience of the patient, along with his identity and personal power. This perspective limits both the understanding we have of disease and health, and the use of the patient's own resources in his recovery process. The bio-psychosocial model is presented as a theoretical approach to counter the biomedical model (Yépez, 2001). The training Psychologists need to work in the public health system still requires changes, changes in both the model of care and in the guidelines of mental health policies that prioritize care for severe cases (Fonseca, 2008).

Health Psychology can apply its principles, techniques and skills to assess, diagnose, treat, modify and prevent the physical and mental problems of individuals. Its main objective is to understand how biological, behavioral and social factors influence the health and illness of individuals. The practice is characterized by primary, secondary and tertiary interventions, in different contexts of development, with prevention, health promotion and educational activities (Bornholdt $\&$ Castro, 2004)

If the changes in recent years in the policies related to the treatment of drug users and the need for coordinating services and providing integrated care is taken into account, it becomes clear that research is needed to understand how the Towns have faced this problem. This study, therefore, will present results on how the towns of Paranhana Valley -Southern Brazil have organized their services and care for crack users in the context of the UHS.

\section{Methodology of Research}

\section{General Background of Research}

This investigation adopted the method of Ecological Insertion (Cecconello \& Koller, 2003; Prati, Paula Couto, Moura, Poletto \& Koller, 2008), which is based on the Bioecological approach of Human Development from Bronfenbrenner. This allows the researcher to monitor and engage in loco in the activities developed by the care services for the crack user, the organization of the services, the interaction with the crack user, the perceptions of the professionals about users, their technical training, the barriers to access that are raised for treatment and the perceptions of the user about the treatment on offer. Trained researchers experienced the daily activities of the services for four hours 
each week during three months. This period was established a priori and considered necessary for Volume 6, 2013 understanding the studied phenomenon.

\section{Sample of Research}

This research investigated 14 care services for crack users in the Paranhana Valley - Brazil linked to UHS. The data related to the following services that compound the Public Health System are discussed: three general hospitals, six PSAC and five BHU. These are all the services available in the area that affirm (by phone contat) that attend crack dependents.

\section{Instrument and Procedures}

First, all services listed in the National Register of Health Facilities (CNES, 2010) and the Guide of Mental Health Services in Rio Grande do Sul (2008) were surveyed by contacting them by phone to verify if they cared for crack users and to provide a brief explanation of the project. A meeting was then scheduled with the head and/or coordinator of the service to present the project. After the approval and agreement to perform the study, the researchers inserted themselves into the services, systematically monitoring the therapeutic proposals. Data was collected based on contacts with both service professionals and users.

The field diary was the main instrument used to record the gathered information, following guidelines for its draft and taking care to address the methodological issues put forth by Morais (2009). It was written by the researcher after completion of each visit and contained the monitored activities, the observed facts, impressions and feelings that occurred to the researcher during his insertion. In addition, informal interviews were conducted with some professionals and crack dependents. Medical records and documents provided by the services were consulted, which helped in the gathering of data and information on the operation of these services. The main research objectives (to know how the public health system is organized and what are the interventions adopted in the different services that attend crack users) served as guidance for the gathered observations and information during the insertion of the researchers.

\section{Data Analysis}

A qualitative and integrated analysis of the information gathered during the insertions was conducted. The field diaries were submitted to content analysis (Olabuenága, 2012) and grouped into categories according to the research objectives. The data were also imported into the NVivo software, which helped to organize, integrate and identify the emerging themes in the diaries.

\section{Ethical Procedures}

The study met the requirements of Resolution No. 196/1996 of the National Health Council and was approved by the Ethics Committee of the Faculdades Integradas de Taquara (2010). All units participating in the study signed a Technical Cooperation Agreement and the professionals and users who granted interviews agreed to participate and signed the consent form.

\section{Results of Research and Discussion}

The Paranhana Valley consists of six towns: Igrejinha, Parobé, Riozinho, Rolante, Taquara and Três Coroas. Table 1 provides information on the towns that participated in this study, such as population and the public health services that compound the care network for drug users. In addition, information is presented on whether these cities realize activities to fight crack and other drugs and on the level of problems related to crack, based on the research of the National Council of Towns (CNN, 2010). 
ISSN 2029-8587

PROBLEMS

OF PSYCHOLOGY

IN THE $21^{\text {st }}$ CENTURY Volume 6, 2013

Table 1. Characterization of the cities of the Paranhana Valley (Population, Services, Actions to fight crack and level of problems related to crack).

\begin{tabular}{|c|c|c|c|c|}
\hline City & Population* & Services & $\begin{array}{c}\text { Actions to fight } \\
\text { crack and other } \\
\text { drugs }\end{array}$ & $\begin{array}{l}\text { Level of problems } \\
\text { related to crack ** }\end{array}$ \\
\hline Igrejinha & 31.660 & $\begin{array}{c}\text { BHU, PSAC, General } \\
\text { Hospital }\end{array}$ & No & Low \\
\hline Parobé & 51.502 & $\begin{array}{c}\text { BHU, PSAC, General } \\
\text { Hospital }\end{array}$ & No & Medium \\
\hline Riozinho & 4.330 & $\mathrm{BHU}$ & No & - \\
\hline Rolante & 19.485 & BHU, PSAC & Yes & Medium \\
\hline Taquara & 54.643 & $\begin{array}{l}\text { BHU, PSAC, PSAC AD, } \\
\text { General Hospital }\end{array}$ & $* * *$ & $* * *$ \\
\hline Três Coroas & 23.848 & $\begin{array}{c}\text { BHU, PSAC, General } \\
\text { Hospital }\end{array}$ & Yes & Medium \\
\hline
\end{tabular}

The services that make up the Psychosocial Care network for crack users of the UHS in the Paranhana Valley are the Basic Health Units, the Psychosocial Care Centers and the General Hospitals with wards specializing in mental health and addiction. Each of these services is organized and operates according to the peculiarities of the UHS, from the state and municipal management to the organization of the competencies of the health network to which they belong.

The contact with these care services indicated that all towns have problems related to the use of crack and other drugs. Almost all investigated services were aware of and concerned with the increase in crack consumption and, consequently, with the demand for care. The way the care network of the towns operates to care for crack users becomes apparent from the patient information shared between departments through the reference and counter reference documents and through the systematic exchange between service professionals. One specialized care service, however, said at the beginning of the insertions that they did not have any crack users in their town. During the research process, crack users accessed the service, asking for attention, forcing the service and its professionals to recognize that they had no knowledge of them.

\section{Primary Health Care: Basic Health Units and Family Health Teams}

The BHU are the gateway for any user into the UHS system. It plays a strategic role in the organization of the flow of the health care network and develops actions that range from promoting to restoring health (Brasil, 2011). The Family Health Strategy (FHS) comprises a strategy that aims to change the current biomedical care model that for years has dominated the healthcare system, incorporating the principles of the Psychiatry Health Reform (Nunes, Jucá \& Valentim, 2007).

The idea of integrated care comprises the provision of contextualized care in the region where the user lives, including the aspects that influence health and disease processes, such as cultural, social, economic and, especially, subjective aspects (Neves \& cols., 2012). This form of care does not allow the compartmentalization of the user. Since it's not possible to care for physical ailments without understanding mental health, the user has to be understood in an integrated and contextualized approach (Nunes \& cols., 2007).

What makes FHS teams different is the fact that they intervene in the environment where people live. This approach enables a broader understanding of the health and disease processes and 
the development of actions that have greater impact and social significance. The prioritization of prevention, disease recovery and health promotion activities within the community, makes it possible to establish bonds of commitment and responsibility between the professionals and the population under care. The attention is humanized and developed in alignment with the resources available in the community itself, which means that the community plays an important social role (França \& Viana, 2006). This active attitude in the treatment, however, did not seem to manifest itself in the treatment of drug addicts in the units investigated.

In the BHU and FHS units where insertions were realized, no activities on a mental health level were offered to the crack users. The users who access the BHU units, do so in in order to seek treatment for injuries (mostly the consequence of fights) and for medical consultations (for physical health problems and, in the case of women, for pre-natal care). "There are many crack users in the neighbourhood. They come to the BHU, but not to seek treatment for their crack addiction" (BHU 2). "BHU Employees know many crack users. Sometimes these users seek out the service to care for other diseases "(BHU 3). In these situations, where the crack user is cared for at the BHU, no mental health care is provided, no effort is made to have an individualized understanding of the case and no strategies are adopted by the team to intervene or to monitor the chemical dependency.

Drug abuse or addiction is only addressed by professionals if the user specifically requests assistance to solve this health problem. If not, they "just care for something that is not related to drug addiction, even if the patient is addicted" (BHU 3). The professionals know the crack users and report that "in the neighbourhood there are many users. They know the names of the users, the houses where they live and who their parents are" (BHU 2). Despite their knowledge about users histories and the risks they run, the professionals do not considered themselves authorized to treat them: "They reported that they cannot go into the houses to offer assistance to the addicts" (BHU 3).

The proximity that the FHSs have to families and communities is a strategic resource to gain access to people who have problems resulting from drug use and also to monitor and refer them to proper attention (Brasil, 2003). The lack of mental health interventions in the primary care network (Nunes \& cols. 2007), however, can further isolate and alienate the user if teams ignore this demand, hampering the development of comprehensive care for their health problems (Neves \& cols. 2012).

Despite the change in health care model, some teams are still organized around the figure of the doctor and the use of medications to deal with mental health demands (Nunes \& cols., 2007). The inadequacy of the practices adopted in primary health care can be linked to actions that are based on the biomedical model, which are discriminatory or moral-repressive in nature. These actions reveal that the teams lack technical training, an understanding of the mental affliction and knowledge of the resources that are available to care for these users (Neves \& cols., 2012).

The crack users, who access the BHU units specifically looking for treatment of their addiction, are advised to seek care at the hospitals or at the PSAC. No effort is made to establish a bond, to assess their case or to provide guidance on the therapeutic process. After the referral (through a written document), the case is not monitored nor is the approach that BHU professionals are taken into consideration by the specialized team. "The two cases that sought out the BHU were referred to the mental health system of the town, to the PSAC. When asked about what feedback they receive from the PSAC on the adherence of the user to treatment, she said there is no follow-up after the referral to check if users arrive or not at the service. It was implied that she had done her part" (BHU 3).

The referral often results in the waiving of responsibility by the basic health teams, who do not understand the therapeutic role that they could play. The specialized services confirm this attitude and they judge the actions and interventions developed in primary care to be unsatisfactory (Neves \& cols., 2012). Responsibility must be shared with the other services in the care network that the user accesses. He will remain a BHU user and the BHU will have to continue developing activities to promote health and to prevent and reduce harm to the user's health. Such a modus operandi will increase the ability to solve problems and encourage the interdisciplinary and joint action between the health services on behalf of the user (Brasil, 2003). In these procedures, there is a smaller chance that the user will go unattended and not receive the needed care (Neves \& cols., 2012).

Only in one city does the BHU provide systematic care for crack users. This care is offered because no other public health services are available in the town, making its BHU unit responsible 
ISSN 2029-8587

PROBLEMS

OF PSYCHOLOGY

IN THE $21^{\text {st }}$ CENTURY Volume 6, 2013

62

for all health demands. The care is provided by a doctor, who exclusively monitors some users, a psychologist and a social worker (BHU 1). When hospitalization is necessary, such cases are referred to the reference hospital and the evolution and return of the user to the town is monitored. The guidelines from the Ministry of Health state that towns with less than 20,000 inhabitants should structure their health care around the primary care services. Support from the overall network and the FHSC can assist HFS teams in this process of taking on responsibility for the comprehensive care of users (Brasil, 2003), in addition to developing care technologies that depart from the biomedical model and consider the idiosyncratic needs of each user (Nunes \& cols., 2007).

Despite the growing demand for the treatment of drug addiction, a significant portion of the population is not addicted, but presents problems that arise from drug use (Brasil, 2003). Given that the actions undertaken in primary care should range from the promotion to the recovery of health, the roles played by the BHU, FHS and FHSC represent an important preventive care resource for people who use drugs, if the concepts of integration, regionalism and bonding with the user are taken into account.

The primary health services should identify and evaluate drug users regarding their degree of functionality (referring to disruptions resulting from the drug use), their vulnerability to physical, psychological and social injuries, and their relationship with the care network (services of the health or the social support network). In cases of vulnerabilities and a history of social disruption, it is up to the BHU to coordinate with the PSAC, to refer the users to specialized care, to discuss individual therapeutic projects and to jointly define the type of care that will be employed, deciding whether these should focus on harm reduction activities or specialized treatment (Brasil, 2010b).

At this level of care, one can observe that psychological treatment is only applied to crack addicts when the city does not have health care units at another level. This creates a sense that they will have to cope with the available resources, which requires the interaction between the professionals working in the same service (the social worker and the general practitioner).

\section{Specialized Psychosocial Care: PSAC and PSAC AD}

The PSAC are the primary resource for mental health care. They should organize the care and attention to drug users and those with severe mental disorders. They are considered to be the main substitute to psychiatric internment and they play a strategic part in the organization of mental health services in the towns and in the expansion and strengthening of the extra-hospital network (Brasil, 2004b). The PSAC AD care specifically for drug users - whether these are children, teenagers or adults - and their families. They should offer individual or group care, workshops, home visits, family consultations, and joint cross sector actions that aim to promote psychosocial rehabilitation (Brasil, 2011).

There are six PSAC in the Vale do Paranhana, of which only one cares specifically for alcohol and drug problems. Its teams are made up of: Psychiatrists, Psychologists, Social Workers, Occupational Therapists, Nurses, Nursing Technicians and Workshop Instructors. Patients are referred to the PSAC from the BHU, Hospitals, spontaneously and, in many cases, by the family members of users.

During the insertions the services were adapting themselves to meet the growing demand of addiction cases. This has overloaded them because there was already a significant mental health demand at the time, which had not been resolved by the management. In addition, there was a lack of guidance and time to restructure the services to care for drug users. The demand for treatment by crack users has been increasing, but even so periods were identified when there were no users in care and/or monitoring. "I asked her what she thought about the decline in treatment of crack users and she replied that the demand for alcohol treatment was higher ... maybe crack users are seeking treatment less often" (PSAC 3). "At the hospital, users go through a treatment in 15 days and believe they are cured. When they come here and ask how long the treatment takes, I say it depends and they do not come back. If the choice is between staying 15 days at the hospital or attending the PSAC for a long time, they end up opting for the hospital" (PSAC 1).

According to Horta, Horta, Rosset \& Horta (2011), the fluctuation in the demand for care is linked to changes in the illicit market, to the abandonment of treatment and to the fact that half the cases monitored by the PSAC have to do with guidance to families. The abandonment of treatment, 
which is very frequent in these cases, and the subsequent re-entry into the care service may give the impression that there are periods with higher demand for care, just as happens in periods when there is a crackdown on trafficking and drug seizures by police.

When users accessed these services for the first time, an interview to assess the complexity of their situation was scheduled. Only in rare cases was this done during the first contact. This last option is a practice that, according to Ribeiro and Laranjeira (2012), could reduce the cases of abandonment during pretreatment. After accepting the person for treatment, the user was usually referred to psychiatric care and, subsequently, to the hospital for detoxification. "The nurse does not think that hospitalization is the best treatment option for all cases, but for the time being, if an addict walks into the service looking for treatment, they accept him/her and refer him/her to a hospital for internment" (PSAC 2). The contacts made after hospitalization, were done for scheduling a psychiatric consultation. The treatment was offered primarily to crack users and involved psychiatric care with the use of medications and this care was administered in the form of individual consultation. The consultations did not exceed 15 minutes, taking less time in many cases, and the next appointment was often scheduled more than 60 days later in a PSAC.

If the services had a psychiatrist on staff, the waiting time for the first consultation was several weeks. Individual psychological care was restricted to rare cases and, in some services, "even with two psychologists on staff, consultations were being scheduled for two months after referral" (PSAC 3). If group care existed, it was done in open groups, bundling all types of drugs users and age groups (from teenagers to adults). The surveyed addicts did not attend the groups often because of the time in which the meetings were held, the shame involved, because they believed it was the medication that would keep them in abstinence and because of the way the meetings were structured.

The adherence of crack users to treatment is just as unpredictable as their search for and abandonment of such treatment. The development of an individual therapeutic plan that, after a detailed assessment of the user, considers his peculiarities and specificities will enable the interventions to really assist in the improvement of his psychosocial functioning. The provision of different therapeutic modalities, of approaches that vary in intensity according to the severity of the case, and of a stable environment may facilitate the users' adherence to treatment, decreasing the chances of relapses and abandonment (Ribeiro \& Laranjeira, 2012).

Family care received no priority in these services. Professionals justified this by stating that family members do not commit with the treatment. "There was a group for relatives that was accompanied by a psychologist, but there was little adherence" (PSAC 1), "the frequency of attendance of family members is not continuous because of work obligations. Only three mothers attend regularly because they do not work every day, are retired or have other occupations that do not require them to keep strict working hours" (PSAC 4). Because of the lack of social workers or interest from the family's part "it is very difficult to attract families to the group, they are always invited to participate, but the family always finds excuses to not participate, they say they can't attend because of work" (PSAC 1). Although the family is not accepted in most services, they are the ones who in most cases have sought help (meaning hospitalization) for the user. "They come spontaneously and are usually brought in by relatives who want their hospitalization" (PSAC 4). It is also the family who needs to keep up with their progress at the hospital and at some primary care services. Only one PSAC offer a treatment for the family of the dependent. It is a group activity that happens once a week. It is an open group, and the participants are all women. The participant reported that "the PSAC has a very important paper in their lives. It is a place where they were heard. During the appointment, they moved far away from the Chemical Dependency that affect mainly their relatives, to talk about themselves and their problems" (PSAC 6).

The inclusion of the family in the PSAC is a very important resource for treating people with mental disorders. In addition to helping the team to access and bond with the user, the monitoring by the family allows them to reframe the way they care for the user. The perception that there is social support is an important predictor for decreasing the overload of the family, which affects the physical and mental health of family members. It is necessary, however, that the PSAC take on responsibility for the care of these families, since their inclusion is part of the care strategy for the user and it is supported by Brazilian legislation (Schein \& Boeckel, 2012).

Although the Ministry of Health (Brasil, 2004a) adopts harm reduction as a strategy in the 
treatment of addiction, all investigated PSAC worked with the logic of abstinence from drugs. At the first contact the user was already sent for consultation with a psychiatrist to issue a report for hospitalization in a general hospital or for detoxification at home.

The PSAC should offer care to crack users without imposing abstinence. Harm reduction is understood as a treatment method that respects the user's freedom of choice, without imposing abstinence, although it is desired. In this approach, the logic of shared responsibility is employed to reduce the social and health damages resulting from drug use (Brasil, 2004a). Instead of a vertical relationship, bonds are prioritized that enhance professional knowledge. The goal is to empower the user in relation to his vulnerabilities, enabling him to reassess his relationship with the drug and to be in charge of his choices (Conte \& cols., 2004).

The harm reduction approach is still being questioned today because of its small effectiveness in the treatment of crack users. The strategies, that start with psychiatric hospitalization and end up referring users to Therapeutic Communities for long periods of time, are those that have shown the best results (Kessler \& Pechanscky, 2008). It is important to note, however, that despite employing different methods, the harm reduction approach ultimately aims for abstinence from any kind of drugs, since it recognizes the damage and harm caused by the use of any psychoactive substance (Brasil, 2004a). It can therefore be thought of as a contact and bonding strategy with the user, which respects his choices, but nevertheless encourages him to take care of his health and well-being, building a proposal that cares for life without the use of drugs. It is therefore of vital importance that the health care network and services on offer are organized based on scientific evidence, the training of professionals and the creation of a cross-sector care network that takes the complexity of addiction into account.

When the treatments available at the PSAC were analysed, it is clear that psychologist plays a central role. Therapeutic groups for this public only happen when it is coordinated by a professional of this field, even if done in partnership with another professional. Because of this the team meeting becomes crucial. During such meeting professionals can develop a line of action that enables an appropriate therapeutic response in each case. Although there are no special interventions for crack dependent, psychological therapy (in group or individual) has proven to be the only strategy that delivers some results when it comes to keeping the addict abstinent.

\section{Hospital Care: Beds and Wards Specializing in Addiction}

Hospital Care is performed by the general hospitals of the towns with a few beds in wards for mental health and addiction. Beds reserved for patients with mental health problems are often used for addicts and this practice is justified based on comorbidities. Not all towns have a general hospital with beds for detoxification and, consequently, they rely on the hospital network. A center in Rio Grande do Sul coordinates the distribution of hospital beds in the region. It is common to have users occupying these beds that are not from the Paranhana Valley.

The Ministry of Health recommends that this type of care should only be used as a last choice, after all the other levels of care have been exhausted (Brasil, 2004a). In all the towns of the Paranhana Valley, hospitalization is seen as the first step in the treatment of crack users. The referral of users to the Hospital for detoxification is perceived as essential for treatment. Only one PSAC attempts, in some cases, to perform the detoxification at home, but in most cases this is followed by hospitalization.

The activities offered to crack users involve psychiatric evaluation with the prescription of psychotropic drugs, therapeutic groups coordinated by Psychologists, Social Workers, Occupational Therapists and Physical Educators. Individual psychological therapy is carried out when this is requested by the user or team. Hospitals also count on the partnership with self-help groups that take place within hospitals and on volunteers who develop recreational, art and relaxation activities. Users engage in activities in the garden at least once a month, which means that not all users participate in this activity. There is also a workshop to renovate and build furniture. Patients can read books available at the hospital, and/or occupying their free time with TV, video games and movies. There is family care, only in those hospitals that require the presence of a family member for hospitalization.

There is a routine to the activities that are developed with users during their hospitalization. 
They have a fixed time for eating, for taking care of their hygiene, for smoking, for therapeutic activities and for their daily visits. Hospitals provide a safe and secure environment and the routine is Volume 6, 2013 important for the organization of the users, to avoid times with nothing to do and to facilitate their adherence to treatment. Despite the efforts of the services to offer several therapeutic and recreational activities during the day, the teams are small and can't always meet the demand.

The specialized wards are one of the care resources of the network that are available for the treatment of drug users. Hospitalization should be considered in cases where the user's life is at risk, such as intoxication, withdrawal, clinical complications, psychiatric comorbidities, or aggression towards others or the user himself/herself. Wards provide a safe and structured environment for detoxification, for assessing comorbidities and for specialized care by a multidisciplinary team. The work done is based on the development of a treatment plan, respecting the characteristics and needs of the user. Since detoxification is the first step in the treatment and aims to treat withdrawal symptoms, these services encourage users to adhere to the ambulatory care services, such as the PSAC, motivating them to access and create bonds with these institutions (Duailibi \& Ribeiro, 2012.)

The teams are multidisciplinary and have being trying to improve the treatment of addiction. Meetings are held weekly, with the participation of the entire technical team to discuss and evaluate the treatment plans of the users. "The patient charts leave room to register the therapeutic plan, which according to a psychologist does not work. The plan's purpose is to avoid situations where one patient receives more attention than others. Some patients demand more and end up getting more. This is something the team has been trying to evaluate constantly, since this is a factor that may contribute to treatment outcome" (Hospital 2).

Many professionals are part of the team from other hospitals and/or services of the network, which makes it possible to monitor some cases after hospitalization or to learn about new hospitalizations to different hospitals. The monitoring of users after the hospitalization period is a matter of concern. They "work in multidisciplinary teams and don't believe that the problem of addiction can be solved only with the hospitalization of the patient" (Hospital 1). Professionals prepare users for their discharge, discuss with them the importance of further monitoring by the PSAC and explain that detoxification is only the first step of the treatment. When he is discharged, the user receives a referral document and is instructed to go to the PSAC to schedule an appointment. The team contacts the PSAC to pass on information about the user and to follow up on whether or not he goes to attend the service.

The hospital is the only place where psychologists work as members of a multidisciplinary team. Despite their unique place and responsibility towards the patient, these professionals work to ensure the necessary treatment. These attitudes force them to deal with problems that are beyond their responsibilities.

The current scenario of care to crack users in the Paranhana Valley involves three levels of care that are still in the process of being organized. This scenario can be summarized as follows:

When the user seeks out help, he comes into contact with the health care system first at the BHU, but its professionals do not authorize themselves to address any other health issues than those that are explicitly mentioned by the user. In addition, these users are not referred to anyone who can properly assess their condition. The user is expected to contact the service, report his crack use and then ask for help. After that, he is referred to a specialized service. When users are referred, the professionals of the BHU do not follow up on the service to check whether the user really did go, to discuss the referral or the way in which they can contribute to the treatment plan. The professionals are not prepared to handle this demand. It's, however, not possible to pass judgment on any lack of interest on the part of these professionals. They have no knowledge in the field of addiction and are not subject to any interventions and trainings in mental health. They are unaware of the important role they could be playing and feel that they are not included in the care network for drug users.

Users arrive at the PSAC after they have been referred by the BHU or the hospitals, or, in many cases, spontaneously accompanied by family members. When this service is accessed for the first time, an interview is scheduled to assess whether the user can be accepted for treatment. In rare cases this is done during this first contact. After their treatment has been authorized, the user is commonly referred to psychiatric care to assess the detox strategy, which almost always entails the referral to a hospital. After hospitalization, the user is contacted to schedule a psychiatric consultation, a standard 
treatment that is often the only type of service the user will get. If there is a therapeutic group, the user is invited to participate, but few crack dependents adhere to this practice. Crack users are rarely referred to individual psychotherapeutic treatment. The short supply of therapeutic modalities for drug users, the lack of care when the user is not abstinent, relapses or abandons treatment, indicate the lack of technical qualification of some professionals in this level of attention. This is amplified by the fact that the services are overloaded with demands for mental health care, which are given priority over addiction problems. Despite the requirement that these services care for drug users, they were already facing a great demand for mental health care. The teams have not been expanded, nor has there been any training, guidance or specialized supervision to reformulate and discuss the strategies that should be adopted. Some professionals locate these teams as coordinators of the care to crack users, not as responsible for the treatment.

The hospitals admit users if they have a medical report issued by the psychiatrists from the PSAC teams, with a court order or in urgent or emergency situations. The user is assessed by the psychiatrist, is medicated, and participates in groups coordinated by Psychologists, Social Workers, Occupational Therapists and Physical Educators, in addition to self-help groups that take place within the hospitals. After the hospitalization period, the user is advised and referred to the treatment of the PSAC of the town where he resides. In most cases the hospital staff will contact the PSAC to inform that the user was discharged, to describe the period of hospitalization, if there were complications, whether he has a family support network and to provide an opinion on which points need to be developed and cared for during outpatient treatment. The hospital teams are better structured and qualified to work with addiction. They are concerned with the follow-up treatment at the PSAC and with the high number of readmissions that occur in short periods of time. Some teams are constantly reviewing their practices, know and assess their shortcomings and difficulties, defend better working conditions (reduced workload, training and hiring of qualified professionals) and better conditions for the users.

\section{Conclusions}

The treatment of crack users presents a challenge to the health care network. It is essential to use different approaches that are based on evidence and aligned with the demands of users. Each service has sought to adapt itself to the changes in the structure, organization and delivery of care in its own specific way. It is clear in this scenario, however, that professional training, greater coordination of the services and a commitment and accountability with the care on offer is needed.

Crack users are at greater risk of developing problems arising from their drug use. The inadequate or non-existent access to the care network (to the health care and social support services), is a consequence of the rupture or the fragility of relations between this network and the user. The lack of training of the teams to deal with this demand is a factor that influences the user's access to health services. When treatment is abandoned, an active search of the user must be conducted and this ought to occur in coordination with the primary care services. The care network for crack users in the Paranhana Valley is gradually organizing itself. Each town has organized itself according to the available care services, the training of its professionals and the resources of the town.

The organization and functionality of the care network for crack users should not remain the desire of a few PSAC and Hospital professionals of the Vale do Paranhana. The responsibility must be shared between all services that make up the Care Network for crack users in the Paranhana Valley. Managing and coordinating mental health agencies are very important at this stage. It promotes discussions on the developed work and the training and/or supervision of professionals. It helps develop interventional strategies for users who are being monitored and it enables to access those who have not yet been contacted by the services, but require care.

The harm reduction approach is still being questioned today because of its small effectiveness in the treatment of crack users. The strategies, that start with psychiatric hospitalization and end up referring users to Therapeutic Communities for long periods of time, are those that have shown the best results. It is important to note, however, that despite employing different methods, the harm reduction approach ultimately aims for abstinence from any kind of drugs, since it recognizes the damage and harm caused by the use of any psychoactive substance. It can therefore be thought of as 
a contact and bonding strategy with the user, which respects his choices, but nevertheless encourages him to take care of his health and well-being, building a proposal that cares for life without the use Volume 6, 2013 of drugs. It is therefore of vital importance that the health care network and services on offer are organized based on scientific evidence, the training of professionals and the creation of a cross-sector care network that takes the complexity of addiction into account.

Some professionals's categories linked to the health network has stressed the importance of Psychology in this field. They are co-responsible for the treatment of addicts, but they only get involved in this treatment in services of greater complexity. The network is overloaded and all professionals are trying to do their best. It is important to recognize that the coordination of work should increase the cohesion of services and demand for a cross-discipline approach, instead of removing the responsibility of professionals from the users in the health system that deal with Crack dependence.

\section{Acknowledgements}

Financial support: $\mathrm{CNPq}$

All researches from Research Group in Community Psychology - Saude.com - from Taquara Integrated Faculties (FACCAT).

\section{References}

Bornholdt, E. \& Castro, E. K. (2004). Psicologia da saúde x psicologia hospitalar: definições e possibilidades de inserção profissional [Health psychology versus hospital psychology: definitions and scope of professional insertion]. Psicologia Ciência e Profissão, 24 (3), 48-57. [DOI: http://dx.doi.org/10.1590/ S1414-98932004000300007]

Brasil (1990a). Lei n. ${ }^{\circ} 8.080$, de 19 de setembro de 1990 [Law 8080, September 19, 1990]. Provides for the conditions for the promotion, protection and recovery of health, the organization and functioning of the corresponding services and other matters. Retrieved January 12, 2013, from http://www.planalto.gov. $\mathrm{br} / \mathrm{CCIVIL} / \mathrm{leis} / \mathrm{L} 8080 . \mathrm{htm}$

Brasil (1990b). Lei no 8.142, de 28 de dezembro de 1990 [Law 8142, December 28, 1990]. Provides for community participation in the management of the Unified Health System (UHS) and on transfers of financial resources in the health and other measures. Retrieved January 12, 2013, from http://www.planalto.gov. br/ccivil_03/Leis/L8142.htm

Brasil (1998). Constituição Federal da República Federativa do Brasil de 1988 [Constitution of the Federative Republic of Brazil from 1988]. Retrieved January 12, 2013, from http://www.planalto.gov.br/ccivil_03/ constituicao/constitui\%C3\%A7ao.htm

Brasil (2001). Lei ${ }^{\circ} 10.216$, de 6 de abril de 2001 [Law 10216, April 6, 2001]. Provides for the protection and rights of people with mental disorders and redirects the mental health care model. Retrieved January 12, 2013, from http://www.planalto.gov.br/ccivil_03/leis/leis_2001/110216.htm

Brasil (2003). Saúde mental e atenção básica: o vínculo e o diálogo necessários [Mental health and primary care: the bond and the necessary dialogue]. Circular Conjunta n. ${ }^{\circ}$ 01/03, de 13 de novembro de 2003. Brasília. Retrieved April 27, 2013, from http://portal.saude.gov.br/portal/arquivos/pdf/diretrizes.pdf

Brasil (2004a). A Política do Ministério da Saúde para atenção integral à usuários de álcool e outras drogas [The policy of the Ministry of Health in integral users of alcohol and other drugs]. Brasília: Ministério da Saúde.

Brasil (2004b). Saúde mental no SUS: os Centros de Atenção Psicossocial [Mental health in the NHS: the Psychosocial Attention Center]. Brasília: Ministério da Saúde.

Brasil (2005a). Reforma psiquiátrica e política de saúde mental no Brasil [Psychiatric reform and mental health policy in Brazil]. Documento apresentado à Conferência Regional de Reforma dos Serviços de Saúde Mental: 15 anos depois de Caracas. OPAS. Brasília. Retrieved April 27, 2013, from http://bvsms. saude.gov.br/bvs/publicacoes/relatorio15_anos_caracas.pdf

Brasil (2005b). Resolução n ${ }^{\circ} / \mathrm{gsipr} / \mathrm{ch} / \mathrm{conad}$, de 27 de outubro de 2005 [Resolution $3 \mathrm{gsipr} / \mathrm{ch} / \mathrm{conad}$, October 27, 2005]. Approves the National Policy on Drugs. Retrieved April 27, 2013, from http://www. obid.senad.gov.br/portais/OBID/biblioteca/documentos/Legislacao/326979.pdf.

Brasil (2010a). Decreto $n^{\circ}$ 7.179, de 20 de maio de 2010 [Decree 7179, May 20, 2010]. Establishing the Inte- 
ISSN 2029-8587

PROBLEMS

OF PSYCHOLOGY

IN THE $21^{\text {st }}$ CENTURY Volume 6, 2013

68

grated Plan to Combat Crack and Other Drugs. Retrieved January 12, 2013, from http://www.planalto. gov.br/ccivil_03/_Ato2007-2010/2010/Decreto/D7179.htm.

Brasil (2010b). Therapeutic approaches to users of cocaine / crack in the Health System: draft text for the public consultation. Retrieved April 27, 2013, from http://portal.saude.gov.br/portal/arquivos/pdf/ abordagemsus.pdf

Brasil (2011). Portaria/GM no 3.088, de 23 de dezembro de 2011[Ordinance/GM 3088, December 23, 2011]. Establishing the Network for Psychosocial Care for people with mental distress or disorder and needs arising from the use of crack cocaine, alcohol and other drugs, as part of the Unified Health System (UHS). Retrieved April 27, 2013, from http://www.brasilsus.com.br/legislacoes/gm/111276-3088.html.

Brasil (2012a). Portaria $n^{\circ} 131$, de 26 de janeiro de 2012 [Ordinance 131, January 26, 2012] . Establishing financial incentive funding for States, Tows and the Federal District to support costing Services Residential Care Regime, including therapeutic communities, aimed at people with needs arising from the use of alcohol, crack and other drugs within the Psychosocial Care Network. Retrieved April 27, 2013, from http://www.brasil.gov.br/crackepossivelvencer/publicacoes/portarias-e-decretos/portaria-No131d e-2012/view.

Brasil (2012b). Portaria $n^{\circ}$ 148, de 31 de janeiro de 2012 [Ordinance 148, January 31, 2012]. Sets the operating standards for Component Hospital Network for Psychosocial Care enabling Hospital Service Reference for attention to people suffering or mental disorder and health needs arising from the use of alcohol, crack and other drugs, e and instituting financial incentives investment and funding. Retrieved April 27, 2013, from http://www.in.gov.br/visualiza/index.jsp?data=01/02/2012\&jornal=1\&pagina=3 3\&totalArquivos $=112$

Brasil (2012c). Portaria ${ }^{\circ}$ 3.124, de 28 de dezembro de 2012 [Ordinance 3124, December 28, 2012]. Resets the parameters linking the cores to support family health (SFH) modes 1 and 2 family health teams and/ or primary care teams for specific populations, creates a modality SFH 3, and other measures. Retrieved April 27, 2013, from http://bvsms.saude.gov.br/bvs/saudelegis/gm/2012/prt3124_28_12_2012.html

Brasil (2013). Portaria $n^{o}$ 615, de 15 de abril de 2013 [Ordinance 615, April 15, 2013]. Provides for the financial incentive investment for construction of Psychosocial Attention Center (PSAC) and Host Units in accordance with the Network for Psychosocial Care for people with mental distress or disorder including those needs arising from the use of crack cocaine, alcohol and other drugs within the Unified Health System (UHS). Retrieved April 27, 2013, from http://www.in.gov.br/visualiza/index.jsp?data= $16 / 04 / 2013$ \&jornal $=1$ \&pagina $=38 \&$ total Arquivos $=84$

Cecconello, A. M., \& Koller, S. H. (2003). Inserção ecológica na comunidade: uma proposta metodológica para o estudo de famílias em situação de risco [Ecological engagement in the community: a methodology for the study of families at risk]. Psicologia: Reflexão e Crítica, 16 (3), 515-524. [DOI: http://dx.doi. org/10.1590/S0102-79722003000300010 ]

CNES (Cadastro Nacional de Estabelecimentos de Saúde) (2010). Estabelecimentos cadastrados no Rio Grande do Sul [Registered establishments in Rio Grande do Sul]. Retrieved March 09, 2010, from http://cnes. datasus.gov.br/Lista_Tot_Es_Municipio.asp?Estado=43\&NomeEstado=RIOGRANDEDOSUL.

CNN (Confederação Nacional Dos Municípios). (2010). Pesquisa sobre a situação do crack nos municípios brasileiros [Research on the situation of the crack in Brazilian municipalities]. Retrieved February 03, 2013, from http://portal.cnm.org.br//sites/9700/9797/Geografia/Atualizado_MapeamentodoCracknosmunicipiosbrasilv4.pdf.

Conte, M., Mayer, R. T. R., Reverbel, C., Sbruzzi, C., Menezes, C. B., Alves, G. T. \& coll. (2004). Redução de danos e saúde mental na perspectiva da atenção básica [Harm reduction and mental health in primary care perspective]. Boletim da Saúde, 18 (1), 59-77. Retrieved June 02, 2013, from http://www.esp. rs.gov.br/img2/v18n1_07redu\%C3\%A7\%C3\%A3o\%20de\%20danos.pdf

Delgado, P. G., \& Cordeiro, F. (2008). A rede de atenção a usuários de álcool e outras drogas na saúde pública do Brasil [The care network users of alcohol and other drugs in public health in Brazil]. In: SUPERA. O uso de substâncias psicoativas no Brasil: epidemiologia, legislação, políticas públicas e fatores culturais: módulo 1. Brasília: SENAD.

Duailibi, L. B., Ribeiro, M., \& Laranjeira, R. (2008). Profile of cocaine and crack users in Brazil. Cadernos de Saúde Pública, 24 (4), 545-557. [DOI: http://dx.doi.org/10.1590/S0102-311X2008001600007]

Duailibi, S., \& Ribeiro, M. (2012). Enfermaria especializada [Specialized Wards]. In: M. Ribeiro \& R. Laranjeira (Orgs.). O tratamento do usuário de crack (pp. 540-547). Porto Alegre: Artmed. 
Ferri, C. P., Laranjeira, R., Silveira, D. X., Dunn, J., \& Formigoni, M. L. (1997). Aumento da procura de tratamento por usuários de crack em dois ambulatórios na cidade de São Paulo, nos anos de 1990 a 1993 [Increase in crack users attending treatment services in São Paulo: 1990-1993]. Revista da Associação Médica Brasileira, 43 (1), 25-28. [DOI: http://dx.doi.org/10.1590/S0104-42301997000100007]

Fonseca, M. L. G. (2008). Sofrimento difuso nas classes populares no Brasil: uma revisão na perspectiva do nervoso [Diffuse suffering in the popular classes in Brazil: a review from the perspective of nervous]. In: E. M. Vasconcelos, A. Klein, C. Freitas \& M. L. Fonseca (Orgs.). Reforma psiquiátrica e saúde mental na ótica da cultura e das lutas populares (pp. 171-223). São Paulo: Hucitec.

França, A. C. P., \& Viana, B. A. (2006). Interface psicologia e programa saúde da família - PSF: reflexões teóricas [Interface psychology and Family Health Program - FHP: theoretical reflections]. Psicologia Ciência e Profissão, 26 (2), 246-257. [DOI: http://dx.doi.org/10.1590/S1414-98932006000200007]

Galduróz, J. C. F., Sanchez, Z. M., \& Noto, A. R. (2011). Epidemiologia do uso, abuso e da dependência de substâncias psicoativas [Epidemiology of the use, abuse and dependence on psychoactive substances]. In: A. Diehl, D. C. Cordeiro \& R. Laranjeira (Orgs.). Dependência química: prevenção, tratamento e políticas públicas. Porto Alegre: Artmed.

Gama C. A. P., \& Koda, M. Y. (2008). Psicologia Comunitária e Programa Saúde da Família: Relato de uma experiência de estágio [Community Psychology and Family Health Program: Report of an internship experience]. Psicologia Ciência e Profissão, 28 (2), 418-429. [DOI: http://dx.doi.org/10.1590/S141498932008000200015]

Horta, R. L. Horta, B. L., Rosset, A. P., Horta, C. L. (2011). Perfil dos usuários de crack que buscam atendimento em Centros de Atenção Psicossocial [Profile of crack users who seek care in Psychosocial Attention Centers]. Caderno de Saúde Pública, 27 (11), 2263-2270. Retrieved June 02, 2013 from http://www. scielosp.org/pdf/csp/v27n11/19.pdf

IBGE (Instituto Brasileiro de Geografia e Estatística). (2010). Censo Demográfico 2010 [Census 2010]. Retrieved February 28, 2013, from http://www.ibge.gov.br/cidadesat/topwindow.htm?1.

Kessler, F., \& Pechansky, F. (2008). Uma visão psiquiátrica sobre o fenômeno do crack na atualidade [A psychiatric view on the phenomenon of crack today]. Revista de Psiquiatria do Rio Grande do Sul, 30 (2), 96-98. Retrieved June 02, 2013, from http://www.scielo.br/pdf/rprs/v30n2/v30n2a03.pdf

Laranjeira, R., Madruga, C. S., Ribeiro, M., Pinsky, I., Caetano, R., \& Mitsuhiro, S. (Coord.). (2012). II Levantamento Nacional de Álcool e Drogas [II National Survey of Alcohol and Drugs]. Retrieved January 20, 2013, from http://www.inpad.org.br/index.php?option=com_content\&view=article\&id=106\&Item id $=9$

Laranjeira, R., Pinsky, I., Zaleski, M., Caetano, R. (Orgs. - 2007). I Levantamento Nacional sobre os padrões de consumo de álcool na população brasileira [I National Survey on patterns of alcohol consumption in the Brazilian population]. Brasília: Secretaria Nacional Antidrogas.

Morais, N. A. (2009). Trajetórias de vida de crianças em adolescentes em situação de vulnerabilidade social: entre o risco e a proteção [Life trajectories of children adolescents in situations of social vulnerability: between risk and protective]. Tese de Doutorado não publicada, Curso de Pós Graduação em Psicologia, Universidade Federal do Rio Grande do Sul, Porto Alegre/RS. Retrieved June 02, 2013 from http://hdl. handle.net/10183/16660

Neves, R., Dimenstein, M., Paulon, S., Nardi, H. Bravo, O., Galvão, V. A. B. M., \& coll. (2012). A saúde mental no sistema único de saúde do Brasil: duas realidades em análise [Mental health in the public health system in Brazil: two realities in analysis]. Avances en Psicología Latinoamericana, 30 (2), 356-368. Retrieved June 02, 2013, from http://www.sci.unal.edu.co/scielo.php?script=sci_arttext\&pid=S1794$47242012000200011 \& \operatorname{lng}=$ pt\&nrm=iso

Nunes, M., Jucá, V. J., \& Valentim, C. P. B. (2007). Ações de saúde mental no programa saúde da família: confluências e dissonâncias das práticas com os princípios das reformas psiquiátrica e sanitária [Mental health care in the Family Health Program: consensus and dissent in practices with the principles of the Psychiatric and Health Reforms]. Caderno de Saúde Pública, 23 (10), 2375-2384. [DOI: http://dx.doi. org/10.1590/S0102-311X2007001000012]

OBID (Observatório Brasileiro de Informações Sobre Drogas). (2010). Editais de ampliação de leitos e serviços de atenção a usuários de Crack e outras drogas e capacitação profissional [Notice of extension of beds and care services to users of Crack and other drugs and professional training]. Retrieved November 01, 2010, from http://www.obid.senad.gov.br/portais/OBID/conteudo/web/noticia/ler_noticia. php?id_noticia $=104290$. 
ISSN 2029-8587

PROBLEMS

OF PSYCHOLOGY

IN THE $21^{\text {st }}$ CENTURY Volume 6, 2013

70

Olabuénaga, J. I. R. (2012). Metodología de la investigación cualitativa [Qualitative Research Methodology]. Bilbao: Universidad de Deusto.

Prati, L. E., Paula Couto, M. C. P., Moura, A., Poletto, M. P., \& Koller, S. H. (2008). Revisando a inserção ecológica: uma proposta de sistematização [Revisiting ecological insertion: a systematization proposal]. Psicologia: Reflexão e Crítica, 21 (1), 160-169. [DOI: http://dx.doi.org/10.1590/S010279722008000100020]

Pratta, E. M. M., \& Santos, M. A. (2009). O processo saúde-doença e a dependência química: interfaces e evolução [The disease process and drug dependence: interfaces and evolution]. Psicologia: Teoria e Pesquisa, 25 (2), 203-211. [DOI: http://dx.doi.org/10.1590/S0102-37722009000200008]

Pulcherio, G., Stolf, A. R., Pettenon, M., Fensterseifer, D. P., \& Kessler, F. (2010). Crack: da pedra ao tratamento [Crack: from Stone to treatment]. Revista da AMRIGS, 54 (3), 337-343. Retrieved in June 02, 2013 from http://www.amrigs.org.br/revista/54-03/018-610_crack_NOVO.pdf

Ribeiro, M. \& Laranjeira, R. (2012). O plano de tratamento [Treatment plan]. In: M. Ribeiro \& R. Laranjeira (Orgs.). O tratamento do usuário de crack (pp. 183-210). Porto Alegre: Artmed.

Rio Grande do Sul (2008). Guia de Saúde Mental [Mental Health Guidance]. Porto Alegre: Governo do Estado do Rio Grande do Sul.

Schein, S., \& Boeckel, M. G. (2012). Análise da sobrecarga familiar no cuidado de um membro com transtorno mental [Analysis of family burden in caring for a member with a mental disorder]. Saúde e Transformação Social, 3 (2), 32-42. Retrieved June 02, 2013 from http://www.incubadora.ufsc.br/index.php/ saudeetransformacao/article/view/1474/1769

Spink, M. J. P. (2003). Psicologia da saúde: a estruturação de um novo campo de saber [Health psychology: the structuring of a new field of knowledge]. In: M. Spink (org). Psicologia social e saúde: práticas, saberes e sentidos (pp. 29-39). Petrópolis, RJ: Vozes.

UN (United Nations). (2012). World Drug Report. New York: United Nations.

Vasconcelos, E. M. (2008). Reforma Psiquiátrica no Brasil: periodização histórica e principais desafios na conjuntura atual Psychiatric Reform in Brazil: historical periodization and main challenges in the current. In: E. M. Vasconcelos (Org.), A. Klein, C. Freitas, M. L. Fonseca. Reforma psiquiátrica e saúde mental na ótica da cultura e das lutas populares (27-55). São Paulo: Hucitec.

Yépez, M. T. (2001). A interface psicologia social e saúde: perspectivas e desafios [The interface social psychology and health: perspectives and challenges]. Psicologia em Estudo, 6 (2), 49-56. [DOI: http:// dx.doi.org/10.1590/S1413-73722001000200007].

Advised by Jefferson Silva Krug, The Pontifical Catholic University of Rio Grande do Sul, Brazil

Received: April 30, 2013

Accepted: June 28, 2013

\begin{tabular}{cl}
\hline Sílvia Schein & Psychologist, Specialist in Drug Dependency and Health Promotion, Faculdades \\
& Integradas de Taquara, Avenida Oscar Martins Rangel, 4500, RS 115, CEP: 95600- \\
& 000, Taquara, Rio Grande do Sul, Brazil. \\
& E-mail: silviaschein@yahoo.com.br \\
& Website: https://psicologia.faccat.br/blog/ \\
\hline Laíssa Eschiletti Prati & Psychologist, PhD. in. Psychology (UFRGS), Professor at Faculdades Integradas de \\
& Taquara, Avenida Oscar Martins Rangel, 4500, RS 115, CEP: 95600-000, Taquara, Rio \\
& Grande do Sul, Brazil. \\
& E-mail: laissa.prati@gmail.com \\
& Website: https://psicologia.faccat.br/blog/ \\
\hline
\end{tabular}

